\title{
Os DiREITOS DA NATUREZA E AS POSSIBILIDAdES DE PROTEÇÃo DO “COMUM": UM ESTUdo COMPARADO ENTRE BRASIL E EQUADOR
}

\author{
Evilyn Scussel ${ }^{1}$, Angélica Pereira Possamai ${ }^{2 *}$ \\ ${ }^{1}$ Programa de Pós-Graduação em Direitos Humanos e Sociedade da UNESC, Universidade do Extremo Sul Catarinense - Unesc \\ ${ }^{2}$ Programa de Pós-Graduação em Direito (PPGD/UNESC), Universidade do Extremo Sul Catarinense - Unesc \\ * Autor para correspondência: angelicappossamai@gmail.com
}

Recebido em 17 de julho de 2018. Aceito em 21 de dezembro de 2018. Publicado em 28 de dezembro de 2018.

REsumo - O presente artigo, intitulado como "Os direitos da natureza e as possibilidades de proteção do "comum”: um estudo comparado entre brasil e equador”, aborda o pensamento de sustentabilidade expresso na Constituição equatoriana de 2008, vinculado ao "buen vivir" (Sumak Kawsay) e aos direitos da natureza, buscando realizar análise comparativa acerca do tratamento jurídico-constitucional conferido ao meio ambiente pela constituição brasileira de 1988. Nesse sentido, destaca-se o necessário cuidado com os bens comuns naturais e a busca por alternativas à racionalidade antropocêntrica e ao modelo de produção e de consumo dominantes. Assim, o objetivo deste estudo consiste em demonstrar a forma como o meio ambiente foi constitucionalizado na constituição do Brasil de 1988 e na constituição do Equador de 2008, comparando o tratamento jurídico-constitucional de ambas as constituições, a fim de detectar qual a legislação encontra-se avançando em direção a uma nova perspectiva de desenvolvimento humano e à construção de uma nova sociedade em harmonia com a natureza. Para alcançar o objetivo proposto, aplicou-se o método dedutivo, com o emprego de procedimento comparativo, juntamente com métodos jurídicos de interpretação sistemático e sociológico, com técnica de pesquisa em documentação indireta com fontes bibliográficas primárias e secundárias.

Palavras-chave: Meio ambiente; Buen vivir; Comum; Constituição brasileira; Constituição equatoriana.

THE RIGHTS OF NATURE AND THE POSSIBILITIES OF PROTECTING THE “COMMON”: A COMPARATIVE STUDY BETWEEN BRAZIL AND ECUADOR

Aвstract - This article, entitled “The rights of nature and the possibilities of protection of the 'common': a comparative study between Brazil and the Equator", addresses the sustainability thinking expressed in the Ecuadorian Constitution of 2008, linked to "buen vivir" (Sumak Kawsay) and the rights of nature, seeking to conduct a comparative analysis of the constitutional treatment conferred on the environment by the Brazilian Constitution of 1988. In this sense, the necessary care is taken with natural common goods and the search for alternatives to anthropocentric rationality and to the model of dominant production and consumption. Thus, the objective of this study is to demonstrate how the environment was constitutionalized in the Constitution of Brazil in 1988 and in the Constitution of Ecuador in 2008, comparing the legal and constitutional treatment of both constitutions in order to detect which legislation is advancing towards a new perspective of human development and the construction of a new society in harmony with nature. In order to reach the proposed objective, the deductive method was applied, using a comparative analysis procedure, together with legal methods of systematic and sociological interpretation, with a research technique in indirect documentation with primary and secondary bibliographic sources.

Keywords: Environment; Buen vivir; Common; Brazilian Constitution; Ecuadorian Constitution. 
LOS DERECHOS DE LA NATURALEZA Y LAS POSIBILIDADES DE PROTECCIÓN DE LO “COMÚN": UN ESTUDIO COMPARADO ENTRE

\section{BRASIL Y ECUADOR}

RESUMEN - El presente artículo, titulado como “Los derechos de la naturaleza y las posibilidades de protección del 'común': un estudio comparado entre Brasil y Ecuador", aborda el pensamiento de sustentabilidad expresado en la Constitución ecuatoriana de 2008, vinculado al "buen vivir" (Sumak Kawsay) y a los derechos de la naturaleza, buscando realizar un análisis comparativo acerca del tratamiento jurídico-constitucional conferido al medio ambiente por la constitución brasileña de 1988. En ese sentido, se destaca el necesario cuidado con los bienes comunes naturales y la búsqueda por alternativas a la racionalidad antropocéntrica y al modelo de producción y de consumo dominantes. Por lo tanto, el objetivo de este estudio consiste en demostrar cómo se ha constitucionalizado el medio ambiente en la constitución de Brasil de 1988 y en la constitución del Ecuador de 2008, comparando el tratamiento jurídico-constitucional de ambas constituciones, con el fin de detectar qué legislación encuentra -se avanzando hacia una nueva perspectiva de desarrollo humano y la construcción de una nueva sociedad en armonía con la naturaleza. Para alcanzar el objetivo propuesto, se aplicó el método deductivo utilizando el empleo de procedimiento comparativo, junto con métodos jurídicos de interpretación sistemática y sociológica con técnica de investigación en documentación indirecta y fuentes bibliográficas primarias y secundarias.

Palabras claves: Medio ambiente; Buen vivir; Común; Constitución brasileña; Constitución ecuatoriana.

\section{INTRODUÇÃO}

O pensamento de sustentabilidade expresso na Constituição equatoriana de 2008, vinculado ao "buen vivir" (Sumak Kawsay) e fundado nas cosmovisões dos povos originários, que viabiliza o equilíbrio e a harmonia do meio ambiente com as comunidades, faz emergir a discussão em torno da questão do "comum" e da idealização de um novo projeto de desenvolvimento humano. Nesse aspecto, a constituição equatoriana articula novas teorias e novas práticas institucionais que apontam para as possibilidades de proteção do "comum".

Diante desse quadro, o presente artigo traz como problema central o seguinte questionamento: quais as distinções e aproximações entre o tratamento jurídico-constitucional conferido aos direitos da natureza nas constituições brasileira de 1988 e equatoriana de 2008 e quais as possibilidades de construção sistemas adequados de proteção dos bens comuns no âmbito dessas constituições?

Assim, a hipótese formulada é a de que há indícios de que o novo pensamento da sustentabilidade presente na constituição equatoriana implica o necessário cuidado com os bens comuns naturais e expressa a busca por alternativas à racionalidade antropocêntrica e ao modelo de produção e de consumo dominantes, enquanto a constituição brasileira de 1988 consolida a centralidade humana sobre a natureza, estabelecendo relação de subordinação e tutela.

Para isso, o objetivo geral consiste em demonstrar a forma como o meio ambiente foi constitucionalizado na constituição do Brasil de 1988 e na constituição do Equador de 2008, comparando o tratamento jurídicoconstitucional de ambas as constituições, a fim de detectar qual a legislação encontra-se em harmonia com as necessidade dos indivíduos e avançando em direção a uma nova perspectiva de desenvolvimento humano e à construção de uma nova sociedade em harmonia com a natureza.

Para isso, no primeiro momento será estudado como o meio ambiente foi tutelado pela legislação brasileira, verificando qual vertente de "bem" o meio ambiente aqui foi enquadrado. Posteriormente, almejou-se analisar o "comum" e a perspectiva do "buen vivir" na constituição equatoriana de 2008, realizando um contraponto da salvaguarda constitucional equatoriana com a brasileira. Parte-se da premissa de que aquela é fruto de lutas sociais nacionais com inúmeras particularidades, não de imposição internacional e dogmática como no Brasil. 
Por fim, será realizado o estudo comparado de tais ordenamentos, com o intuito de ressaltar a necessária construção de sistemas adequados de proteção do "comum" e dos direitos da natureza no Brasil, a exemplo do Equador.

O presente estudo consiste em uma pesquisa empírica que tem como objeto a norma de direito e as demais realidade social ambiental, com o fim de diagnosticar a harmonia/dicotomia entre a ordem jurídica abstrata e a ordem social concreta. Como método de abordagem foi utilizado o método dedutivo, sob o método de procedimento comparativo, juntamente com métodos jurídicos de interpretação sistemático e sociológico, com técnica de pesquisa em documentação indireta com fontes bibliográficas primárias e secundárias. (Oliveira 1999).

\section{O MEIO AMBIENTE NO ORDENAMENTO JURÍDICO BRASILEIRO}

Em junho de 1972 a Organização das Nações Unidas organizou em Estocolmo, na Suécia a 1ª Conferência das Nações Unidas sobre o Meio Ambiente, aprovando, ao final, a Declaração Universal do Meio Ambiente, a qual declarou que os recursos naturais, como a água, o ar, o solo, a flora e a fauna, devem ser conservados em benefício das gerações futuras. Declaração esta que equivale à Declaração dos Direitos do Homem, tamanha a importância deste bem de uso comum do povo e essencial à sadia qualidade de vida. (Lanfredi 2002).

Reafirmam tal contexto os autores Préve et.al nos seguintes termos: "a partir desta Conferência de Estocolmo, capital da Suécia, os Estados iniciaram um processo de reconhecimento normativo do meio ambiente como um direito e um dever fundamental, promovendo assim a perspectiva de proteção dos direitos humanos." (2016, p. 17). Acrescentando que, com a evolução internacional no contexto ambiental, e frente à necessidade de constitucionalização da proteção ao meio ambiente, o grande marco jurídico brasileiro se deu com a Constituição Federal de 1988, que acrescentou a proteção do direito ao meio ambiente ecologicamente equilibrado como direito fundamental. (Préve et al 2016).

No entanto, o meio ambiente por muitas décadas não foi tutelado pelo ordenamento jurídico brasileiro, passou a ser mencionado somente a partir da década de 1980, fruto de pressões internacionais, por meio da edição de três diplomas legais que marcaram a tutela do meio ambiente no Brasil, quais sejam, a Lei no 6.938/81, que dispõe sobre a Política Nacional do Meio Ambiente, a Lei da Ação Civil Pública (Lei no 7.347/85), que disciplinou a ação civil pública como instrumento de defesa do meio ambiente e a Constituição Federal de 1988 que dedicou um capítulo inteiramente em defesa ao meio ambiente ${ }^{1}$, salvaguarda constitucional fruto da consciência ambiental internacional.

Dar-se-á ênfase ao que a Constituição Federal de 1988 estabelece sobre o meio ambiente, a qual determina em seu art. 225 que todos têm direito ao meio ambiente ecologicamente equilibrado, bem de uso comum do povo e essencial à sadia qualidade de vida, impondo-se ao Poder Público e à coletividade o dever de defendê-lo e preservá-lo para as presentes e futuras gerações. (Brasil 2018a).

A partir do marco jurídico constitucional brasileiro de 1988 o poder público junto à coletividade passa a ter o dever constitucional de defesa, preservação e garantia do direito categorizado como direito fundamental ao meio ambiente ecologicamente equilibrado, por ser bem de uso comum do povo, essencial para a sadia qualidade de vida,

1 Posteriormente foram surgindo normas infraconstitucionais mais específicas, como a Lei 9.605/1998, que trata-se da Lei dos Crimes Ambientais, a qual traz punições aos infratores do meio ambiente, como por exemplo, a possibilidade de penalização das pessoas jurídicas no caso de ocorrência de crimes ambientais. Bem como a Lei 12.305/2010 que institui a Política Nacional de Resíduos Sólidos, estabelecendo diretrizes à gestão integrada e ao gerenciamento ambiental adequado dos resíduos sólidos, definindo que todo resíduo deverá ser processado apropriadamente antes da destinação final e que o infrator está sujeito a penas passivas, inclusive, de prisão. A Lei 6.938/1981 que dispõe sobre a Política e o Sistema Nacional do Meio Ambiente, a qual institui que o poluidor é obrigado a indenizar danos ambientais que causar, independente da culpa, e que o Ministério Público pode propor ações de responsabilidade civil por danos ao meio ambiente, como a obrigação de recuperar e/ou indenizar prejuízos causados. Ainda, a Lei 9.433/1997, Lei de Recursos Hídricos que Institui a Política e o Sistema Nacional de Recursos Hídricos definindo a água como recurso natural limitado, prevendo a recuperação de informações sobre recursos hídricos. A Lei 12.651/2012, Código Florestal Brasileiro, que trata da proteção do meio ambiente natural como obrigação do proprietário mediante a manutenção de espaços protegidos de propriedade privada, divididos entre Área de Preservação Permanente e Reserva Legal. (Tera Ambiental 2015). 
sendo suscitado "a utilização de todos os meios legislativos, administrativos e judiciais necessários à sua efetiva proteção, por possuir um regime jurídico especial que exorbita o Direito Comum” (Moraes 2011, p.869).

Com isso, o meio ambiente passou a ser considerado essencial à sadia qualidade de vida, recebendo status constitucional, não só em prol a coletividade atual, mas especialmente às futuras gerações, devendo, por isso, todas as condutas do poder público estatal voltarem-se a integral proteção legislativa interna (Moraes 2011).

Fiorillo (2011) explica que o bem ambiental merece tutela tanto do "poder público como de toda a coletividade", não devendo ser considerada uma simples norma, mas como um dever de ambos. Acrescenta a este viés, Canotilho (2008, p. 181), no sentido de que "a consideração do ambiente como tarefa ou fim normativo-constitucionalmente consagrado implica a existência de autênticos deveres jurídicos dirigidos ao Estado e demais poderes públicos", tornando o direito ao meio ambiente um direito indisponível, uma vez que não há margem de escolha ao Estado no sentido de dever ou não proteger o meio ambiente, “a imposição constitucional é clara: devem!”.

Reconheceu-se constitucionalmente a estrutura finalística do direito ambiental, por meio do uso da expressão "sadia qualidade de vida", caracterizando-o como bem de uso comum, e que juntamente com a expressão "essencial" do caput do artigo 225, fixam o "piso mínim vital", tendo em vista que a Constituição Federal/88 trata o meio ambiente como direito essencial para a sadia qualidade de vida (Fiorillo 2011, p. 65).

Conforme Fiorillo (2011, p. 66) a preservação e defesa do bem coletivo ambiental não direciona-se somente ao presente, mas principalmente ao futuro, e para isso prevê uma tutela de ampla responsabilidade social e governamental ao dispor que cabe ao Poder Público e à coletividade o dever de defendê-lo e preservá-lo para as presentes e futuras gerações.

Assegurou-se, ainda, no dispositivo 225, que aquele que explorar recursos minerais fica obrigado a recuperar o meio ambiente degradado; tornou, ainda, as condutas que lesionam o meio ambiente, possíveis de serem sancionadas penalmente, administrativamente e civilmente, conjuntamente. Sendo de competência comum de todos os entes federativos, conforme artigo 23, incisos a seguir especificados, da $\mathrm{CF} / 88$, o dever de proteção às paisagens naturais notáveis e aos sítios arqueológicos (inciso III), juntamente com o combate à poluição em qualquer de suas formas (inciso VI) e a preservação das florestas, da fauna e da flora (inciso VII) (Moraes 2011, p. 873-874).

A Constituição Federal de 1988 consagrou, tamanha a necessidade, um bem que não é público, tampouco privado, estruturando, desta forma, uma diferenciada tutela ao meio ambiente, a partir do reconhecimento de particularidades presentes neste bem, desvinculando-o dos institutos civis de posse e propriedade, inovando a concepção ligada a direitos, criando o chamado direito difuso ao meio ambiente ecologicamente equilibrado (Fiorillo 2011).

Nesse viés, o meio ambiente ecologicamente equilibrado é "direito de todos", ou seja, direito assegurado a todos, sendo indefinido a sua titularidade, pois é de caráter coletivo. Portanto, é de interesse difuso - uma vez sendo essencial para a sadia qualidade de vida - e transindividual, que são aqueles que “[...] transcendem o indivíduo, ultrapassando o limite da esfera de direitos e obrigações de cunho individual, tendo um objeto indivisivel, tratando-se de um objeto que ao mesmo tempo, a todos pertence, mas ninguém em específico o possui" (Fiorillo 2011, p. 56-57).

O direito de propriedade do ordenamento jurídico brasileiro abrange os elementos usar, fruir, gozar e dispor do bem, explicando Fiorillo que este entendimento restou inovado por meio do entendimento de "bem ambiental", pois este não pode ser apropriado individualmente como a propriedade privada, criando-se a partir disso um "terceiro gênero de bem”, o qual não se confunde com bens privados ou bens públicos (Fiorillo 2011).

Com a Constituição Federal de 1988 confere-se ao meio ambiente o status de bem jurídico, passando a ser "um bem jurídico em si mesmo considerado", não por coexistir nele valores sentimentais, emocionais, mas sim por possuir valor econômico. Com isso, o meio ambiente passa a ter relevancia jurídica, uma vez que, segundo interpretação realizada da obra Instituições de Direito Civil de Caio Mário da Silva Pereira, somente aquilo que a ordem jurídica reconhece como bem pode ser objeto de direito, ou seja, de ação judicial e de relações jurídicas. . 
Sendo a consequência prática deste conceito a necessidade de criação de "instrumentos hábeis à conferir efetiva proteção ao meio ambiente" (Souza 2010, p. 26; 29).

Tornar o meio ambiente bem de uso comum do povo "constituem uma das modalidades dos chamados bens do domínio público do Estado, que encontra nos chamados bens de uso especial.". Destacando que "se consideram bens de uso comum do povo aqueles que, por determinação legal ou por sua própria natureza, podem ser utilizados por todos em igualdade de condições, sem necessidade de consentimento individualizado por parte da administração". Diante de tal categorização "por se tratarem de bens que podem ser utilizados por qualquer pessoa do povo, coletiva ou individualmente, esta utilização se reveste em típico direito constitucional que, pela indeterminação dos agentes que podem exercê-lo, recebe o nome de direito difuso" (Souza 2010, p. 29; Di Pietro 1994, p. 42; Souza 2010, p. 29).

Diante de tais premissas, a Constituição Federal de 1988 dispôs como uma das ferramentas jurídicas hábeis para a proteção ambiental a Ação Popular, com ela garantiu-se que qualquer cidadão é parte legítima para sua propositura visando à anulação de ato lesivo ao meio ambiente (art. $5^{\circ}$, LXXIII). A Ação popular é considerada um "remédio constitucional" regulamentada pela Lei no 4.717, de 29 de junho de 1965, sendo uma das ferramentas de proteção aos interesses públicos, porém esta especificamente dá titularidade aos cidadãos de ajuizarem ação frente a atos lesivos ao patrimônio da União, como os bens de valor econômico, artístico, estético, histórico ou turístico, ou seja, em defesa do direito fundamental coletivo ao meio ambiente ecologicamente equilibrado. Assegurando, neste contexto, "O meio ambiente como direito difuso e sua proteção como exercício da cidadania" (Moraes 2011; Brasil 2018d; Souza 2010).

Por fim, visualiza-se que a constituição brasileira tratou o meio ambiente como bem de uso comum do povo, não definindo titular determinado, uma vez que atribui-lhe natureza jurídica difusa, direcionando à coletividade como responsável por sua tutela jurídica, incumbindo ao poder público e aos cidadãos o dever de defender e preservar o meio ambiente para as presentes e futuras gerações.

\section{O “COMUM” E A PERSPECTIVA DO “BUEN VIVIR" NA CONSTITUIÇÃO EQUATORIANA DE 2008}

A partir da década de 1990 emerge na história da América Latina um ciclo civilizatório de lutas, baseado nos saberes e cosmovisões ameríndias e relacionado às "[...] demandas de reconhecimento dos povos e nacionalidades indígenas subsumidos historicamente e, atualmente despojados com as novas ofensivas capitalistas de privatização dos bens comuns" (Wolkmer e S. Wolkmer 2017, p. 33).

Esse ciclo inicia, na concepção de Carlos Rivera Lugo (2017) com a insurreição zapatista de Chiapas, precursora desse processo, cujas experiências pautadas no comum foram construídas a partir das lutas organizadas desde a comunidade, servindo de eixo das transformações constitucionais recentes ocorridas no continente.

Tal processo, desde o movimento zapatista da década de 1990 no México até os levantes da guerra da água e do gás na Bolívia refere-se à luta contra a “[...] expropriação da produção social local, dos recursos naturais, das terras e dos territórios, como decorrência do processo de globalização do capital [...]", buscando alternativas desde as comunidades (Bernardes 2017, p. 220).

As lutas ocorridas na América Latina pela descolonialidade, desde o processo de independência e libertação dos povos até a defesa dos recursos ambientais e culturais contra a expropriação neoliberal e o domínio da globalização do capital, apresentam-se como uma forma de "institucionalização" e/ou "constituição do comum" e de um "direito do comum", dando visibilidade a outras formas de pensar a "ecologia política, o direito e a perspectiva constituinte ecológica do comum” (Bernardes 2017, p. 28).

Nesse contexto, o Bem Viver emerge das sociedades historicamente marginalizadas e se projeta como plataforma para a busca de soluções concretas urgentes aos problemas para os quais o modelo de desenvolvimentismo atual não consegue resolver (Acosta e Gyodynas 2012). 
A constituição no novo constitucionalismo latino-americano ${ }^{2}$ assume características distintas ao modelo tradicional moderno, alinhando-se ao pensamento de Wolkmer (2013 p.19-20), segundo o qual, “[...] a constituição não deve ser tão somente uma matriz geradora de processos políticos, mas uma resultante de correlações de forças e de lutas sociais em um dado momento histórico do desenvolvimento da sociedade [...]" materializando uma "[...] forma de poder que se legitima pela convivência e coexistência de concepções divergentes, diversas e participativas".

Nessa perspectiva, a Constituição deve ser um "projeto político de vida em comum, elaborado e posto em vigência com o concurso ativo da sociedade" (Acosta 2010, p. 5).

Wolkmer (2013) aponta como autêntica precursora do "novo" constitucionalismo a Constituição da República Bolivariana da Venezuela de 1999, que, de caráter independentista e anticolonial, visava à refundação da sociedade venezuelana, tendo consagrado o pluralismo político como um de seus valores supremos.

A principal etapa no constitucionalismo latino-americano, contudo, é representada pelas constituições do Equador (2008) e da Bolívia (2009)³ , cuja redação traz importantes inovações.

Conforme Wolkmer (2013), a Constituição do Equador de 2008 representa um momento de grande impacto no novo constitucionalismo latino-americano, em razão do seu "giro biocêntrico", fundado nas cosmovisões dos povos indígenas, que assegura direitos próprios à natureza e direitos ao desenvolvimento do bem viver. Trouxe, ademais, importante mudança no tocante à jurisdição indígena (art. 171) e ao fortalecimento do princípio da interculturalidade do direito à educação, que trata do diálogo intercultural. Entretanto, as inovações de maior relevância versam sobre os princípios e o regime dos direitos do "bem viver", assim como sobre a introdução da natureza como sujeito de direitos.

Ora, a partir da inclusão de direitos da natureza, oriundos das cosmovisões indígenas remodelando a relação homem-cultura-natureza, bem como dos conceitos de sumak kawsay, é possível verificar a real dimensão das inovações trazidas pelo novo constitucionalismo latino-americano (Bernardes 2017).

Pautada no conceito da vida expressa no "buen vivir", a nova Constituição equatoriana de 2008 busca o "bem viver" para todos os seres humanos "respeitando os direitos da própria "mãe" natureza, patrimônio comum da vida" (Grzybowski 2012, p. 17). Contrapõe-se, como consequência, à estratégia desenvolvimentalista do ter e acumular (Wolkmer e S. Wolkmer 2016),

Nesse sentido, o "buen vivir" na Constituição do Equador expressa uma nova perspectiva de desenvolvimento, dando ênfase às ideias de autonomia comunitária, reciprocidade social, respeito pelos ecossistemas naturais e moralidade cósmica, intentando romper com o instrumentalismo racional e a mentalidade econômica do capitalismo (Bollier 2016).

O "buen vivir", portanto, resgata a concepção de boa vida e bem-estar em um sentido mais amplo, "transcendendo os limites do consumo material, e recuperando os aspectos afetivos e espirituais." Assim, pode ser entendido como uma "plataforma de encontro de diferentes maneiras de se entender o mundo, e o nosso papel nele [...] é uma plataforma para o debate político sobre as alternativas ao desenvolvimento [...]" (Acosta e Gudynas 2012, p. 11).

Tratando especificamente dos princípios do sumak kawsay o suma qamaña, sustenta Alejandro Medici (2011):

Elprincipio fundamental del sumak kawsay o suma qamaña, -buen vivir-, tomado de la cultura ancestral de las comunidades andinas implica esta visión holista y relacional de la interacción entre sociedad y medio natural como marco necesario de la realización del ser bumano. [...] La idea fuerza del buen vivir pretende volver a poner en ciclo a los seres bumanos con lo social y lo natural, formando una matriz de la que depende el sustento y proliferación de la vida [...] (Medici 2011 p. 112-113).

2 Conforme Viciano Pastor e Martínez Dalmau (2011), existe uma série de características que diferenciam no âmbito formal e material o novo constitucionalismo latino-americano e o constitucionalismo anterior.

3 Como desfecho do ciclo constitucional latino-americano, Wolkmer (2013) introduz a constituição boliviana de 2009 como um dos mais contundentes exemplos de transformação institucional que se experimentou nos últimos tempos, na medida em que avança para um modelo de Estado plurinacional e estabelece o primeiro Tribunal Constitucional eleito diretamente pelos cidadãos. 
Nessa perspectiva, o buen vivir, a partir de uma visão relacional e de interação do homem/natureza como condição para a manutenção e produção da vida, implica na superação da civilização do "ter e acumular" e, consequentemente, em uma profunda mudança de mentalidades e de práticas, que traz como núcleo a questão dos bens comuns, como os bens que pertencem a toda a coletividade. "O bem viver tem como pressuposto o compartilhamento dos bens comuns, como condição da vida." Trata-se de "organizar a sociedade em torno aos bens comuns" e de "revalorizar a coletividade como condição da própria sustentabilidade" (Grzybowski 2012).

Assim, as inovações de maior impacto inseridas na Constituição do Equador de 2008 dizem respeito aos direitos do "bem viver" e aos dispositivos que versam sobre biodiversidade e recursos naturais, pois, rompendo com a tradição constitucional clássica, introduz a natureza como sujeito de direitos (Wolkmer 2013). Ou seja, de objeto de propriedade, a natureza passa a sujeito de direitos, resgatando o "direito à existência dos próprios seres humanos", por meio da manutenção dos sistemas de vida (Acosta 2010, p. 18).

Consequentemente, o "buen vivir" é considerado núcleo central de todo o projeto constitucional equatoriano, expressando a concepção de boa vida proveniente das culturas indígenas da América do Sul (Wolkmer 2013).

A Constituição equatoriana faz referência à realização dos bens comuns, consagrando a água, a alimentação, o ambiente sadio, a cultura, a educação, o habitat, a moradia, a saúde, o trabalho e a segurança, como bens associados à vida e ao bem viver (Wolkmer 2013).

Com efeito, a partir de uma perspectiva normativa,

o Buen Vivir redefine e funda direitos coletivos, compondo um núcleo axiológico com elementos determinantes da cosmovisão andina, e novas formas cognitivas dos saberes e práticas comunitárias, ampliando e agregando percepções plurais de propriedade, onde os territórios com seus ecossistemas estão conectados e são pensados com uma lógica diferente da acumulação/progresso para o crescimento econômico (Wolkmer e S. Wolkmer 2017, p.6).

Pelo exposto, é possível concluir que a constituição equatoriana de 2008 se propõe a realizar uma mudança radical em comparação ao regime constitucional brasileiro, cuja experiência pode ser considerada paradigmática no atual cenário de crise do capitalismo global, demonstrando a possibilidade e a necessidade de pensar e agir para além da lógica estatal e apresentando-se como um polo que articula novas teorias e novas práticas institucionais que apontam para as possibilidades concretas do comum, em direção a um sistema de vida voltado aos ecossistemas e à coletividade (Acosta 2010).

Enfim, esse momento político vivenciado na América Latina, especificamente expresso na Constituição do Equador (2008), representa o (re)surgimento das cosmovisões andinas historicamente encobertas pela matriz epistêmica eurocêntrica e o surgimento de alternativas como o "novo" constitucionalismo latino-americano e o bem comum.

O processo constitucional equatoriano na seara ambiental ocorreu de forma diferenciada do Brasil, pois neste a salvaguarda constitucional de preservação ambiental não é precedida de movimentos sociais nacionais, tratando-se apenas da implementação de recomendações internacionais. Tal contexto explica o motivo pelo qual há tratamento diferenciado entre o ordenamento jurídico brasileiro e o equatoriano com relação ao meio ambiente, enquanto aquele traz o termo "meio ambiente" com perspectiva mais voltadas à necessidade de preservação em prol do fluxo econômico, com perspectiva dogmática pura, este, além de trazer o termo "natureza" e de tornála pessoa de direitos, ainda é fruto de uma perspectiva histórica andina de "“"mãe" natureza, patrimônio comum da vida", fundamentando-se nas cosmovisões dos povos indígenas, que assegura direitos próprios à natureza e direitos ao desenvolvimento do bem viver, contexto que remodela a relação homem-cultura-natureza, com fortes características do comunitário, do comum.

Portanto, o modelo equatoriano contrapõe-se com a realidade assegurada pelo ordenamento jurídico brasileiro, podendo servir de modelo para o Brasil. São vertentes diferentes, enquanto uma carrega fortes traços liberais, 
capitalistas, a outra quebra este paradigma e constitucionaliza as lutas de seus povos originários, implementando uma política voltada a real preservação ambiental, em que resgatou-se a sua própria cultura. Entretanto, o mesmo não pode ser dito com relação ao Brasil.

\section{A NECESSÁRIA CONSTRUÇÃo DE SISTEMAS ADEQUADOS DE PROTEÇÃo DO "COMUM" E DOS DIREITOS DA NATUREZA NO BRASIL}

Historicamente, a modernidade e o sistema de produção capitalista se estabeleceram sobre a criação e reprodução de um sujeito completamente afastado das relações materiais com a natureza, cuja subjetividade foi marcada por "[...] um antropocentrismo radical, por uma relação de poder do homem sobre as demais formas de vida." (Bernardes 2017, p. 253).

Tal sujeito absoluto considera a natureza apenas um meio de desenvolvimento que deve ser preservado para garantir o desenvolvimento dos demais indivíduos, não considerando que a natureza tenha em si algum direito e não prestando contas de sua liberdade ao meio ambiente e às demais formas de vida (Ferrazzo 2015). Contexto que, como se viu, está presente no ordenamento jurídico brasileiro na seara ambiental.

O modo de produção da vida moderna, contudo, desembocou na crise ecológica, que, especialmente a partir da década de 1960, resultou em discussões sobre o meio ambiente ecologicamente equilibrado e no reconhecimento de um direito ambiental como um direito fundamental do homem, como na Conferência das Nações Unidas sobre Meio Ambiente Humano, em Estocolmo, 1972, que gerou certo “[...] "consenso global” no que se refere à necessidade de repensarmos os modos de organização social, econômica e política, próprios da modernidade, especialmente em face da chamada "crise ambiental" (Bernardes 2017, p. 256).

Entretanto, tomando a própria Constituição brasileira de 1988 como exemplo, ainda que tão celebrada por oferecer diversos mecanismos de proteção ambiental, não consegue transcender as limitações do antropocentrismo enraizado historicamente. $\mathrm{O}$ artigo 225 , base constitucional da proteção ao meio ambiente no país, atribui ao Estado e à Sociedade a obrigação de garantir e promover um meio ambiente ecologicamente equilibrado.

O que se percebe é que, conforme abordado no primeiro item do presente estudo, a redação de todo o artigo expressa a centralidade humana sobre a natureza, que é traduzida em "bem de uso comum do povo", cuja proteção fundamenta-se na compreensão de que a natureza é condição de existência do ser humano e de todo o modo de vida moderna, estabelecendo relação de subordinação e tutela.

Ora, ao abordar as experiências recentes ocorridas no continente latino-americano, visualiza-se que a cosmovisão indígena é radicalmente distinta da racionalidade antropocêntrica presente na dogmática constitucional tradicional. Ao antropocentrismo eurocêntrico moderno, o novo constitucionalismo latino-americano opõe o ecocentrismo, com sua manifestação mais perfeita na Constituição do Equador, onde se reserva um capítulo inteiro para dos direitos da natureza da "Pacha Mama" (Ferrazo 2015, p. 200).

A Constituição Política do Equador de 2008 dispõe em seu título II, Capítulo Sétimo:

Art. 71. A natureza ou Pacha Mama, onde se reproduz e realiza a vida, tem direito a que se respeite integralmente a sua existência e a manutenção e regeneração de seus ciclos vitais, estrutura, funções e processos evolutivos (tradução livre da autora).

Diferentemente da Constituição do Equador, que eleva a natureza à condição de sujeito de direitos, a Constituição Brasileira protege o ambiente apenas para preservá-lo, com características utilitaristas, concebendo o mundo em função dos bens "úteis", passíveis de serem usufruídos e negociados, rompendo com as conexões sociais (Helfrich 2008b). 
Para Brandão (2013):

É evidente, portanto, que reconhecer direitos à natureza desafia a própria dogmática constitucional tradicional, pois o meio ambiente, de um instrumento para os desejos humanos, passa a ser ressignificado para um local em que atua em sinergia com os desejos humanos, sem relação de subordinação ou tutela, fruto principalmente da cosmovisão indígena [...] (Brandão 2013, p. 122).

A constitucionalização dos Direitos da Pachamama, conforme apontado na segunda seção do presente artigo, resulta no reconhecimento do meio ambiente como sujeito de Direitos, como expressão do conhecimento e da cosmovisão indígena. "Não se trata apenas de um "meio ambiente ecologicamente equilibrado", como afirma a Constituição brasileira, mas vai muito além” (Brandão 2013, p. 123).

Trata-se do deslocamento do antropocentrismo para o Biocentrismo, em que a vida possui valor em si mesmo e o meio ambiente não tem apenas valor de mercado. "Não há hierarquia entre as diferentes formas de vida, mas todos são naturalmente iguais" (Brandão 2013, p. 123).

Nesse sentido, as transformações ocorridas recentemente na América Latina pautaram-se na articulação de novas relações sociais e políticas e na multiplicidade de lutas coordenadas desde a comunidade, culminando no processo de construção do comum e de uma nova relação entre homem e natureza no sentido de repensar o processo “civilizatório” (Rivera Lugo 2017).

Nesse aspecto, o comum identifica-se com o novo constitucionalismo latino-americano, especialmente com a Constituição do Equador (2008) a partir de sua articulação com os conceitos de Bem viver (sumak kawsay/suma qamanã) (Bernardes 2017).

Silke Helfrich (2008a p. 22, tradução própria) afirma que a crise ecológica e as mudanças climáticas que ameaçam a existência de boa parte da população mundial, o desmantelamento dos comuns e a ruptura cultural e social desencadearam um processo paralelo de emergência de novos bens comuns, apontado para a possibilidade se construir "um futuro sustentável, justo e radicalmente democrático" por meio de uma economia que compreenda a necessidade de proteção, recuperação e ampliação dos comuns.

Assim, conforme Rivera Lugo (2017 p. 3219), o comum corresponde às nossas riquezas, sejam elas sociais ou naturais,

Se trata de la autodeterminación y la soberanía como la gobernanza de todos, por todos y para todos. Lo común es nuestro modo de estar juntos, y cooperar los unos con los otros em torno a fines consensuados que contribuyen al buen vivir. Lo común se encarna en todos y todas. Lo común es de todos y todas.

Silke Helfrich (2008b), abordando a questão do "comum", conclui que a tradução do conceito abrange tanto os bens comuns ${ }^{4}$, quanto o elemento social. Nesse sentido, o termo expressa, na visão da autora, a relação entre as pessoas e seu entorno cultural e natural, e ainda, o sentido de gestão dos recursos comuns. Um recurso, a partir dessa concepção, seja qual for o seu regime de propriedade, consistirá em um comum, na medida em que as pessoas inseridas em suas comunidades sintam-se vinculadas a ele, façam uso de seu patrimônio e permaneçam interessadas em sua conservação e ampliação.

Para a autora, comum são os espaços, os artefatos, os eventos e as técnicas culturais que são de uso e gozo comum e cuja posse coletiva implica direitos, responsabilidades, restrições e consciência da relação vital entre entes e seus recursos comuns (Helfrich 2008b).

Para se avançar nessa perspectiva, Andrés Barreda (apud Helfrich 2008b) afirma que se faz necessário afastar o enfoque "coisificado" quando da abordagem do comum, pois, ao tratar um "common" como "coisa comum", 
se está afastando o sentido de que consiste em uma relação social vinculada à ideia de diversidade de recursos, comunidades e de formas de gestão, em direção à uma visão puramente utilitarista.

Nessa perspectiva, segundo Bernardes (2017 p. 202-203), o comum é compreendido de forma mais ampla que os bens comuns, bens da natureza (ar, água, serviços públicos, etc.), "[...] mas como relação estabelecida no todo, em todas as relações entre homem, cultura e natureza, que é eclipsada e controlada pelas estruturas construídas e constituídas pelo capitalismo moderno".

$\mathrm{Na}$ análise do autor, as próprias estruturas e instituições modernas são formas de enclausuramento do comum, "[...] barragens de contenção que impedem que o comum seja efetivamente reapropriado socialmente" (Bernardes 2017, p. 202-203).

Nessa perspectiva, o "comum" constitui-se em paradigma que abrange os recursos físicos e intangíveis relacionados a uma comunidade determinada com todo o conjunto de protocolos sociais, ou seja, com todas as práticas, valores e normas voltadas para a gestão desses recursos em benefício da comunidade (Bollier 2016).

Flórez (2008) aponta que tal conceito está de acordo com a ideia de mundo defendida pelos povos indígenas da América Latina, para os quais a terra e os elementos da natureza têm uma visão distinta das noções de recursos naturais ou de bens que implicam uma utilidade.

Diversamente, "la relación con el medio ambiente se blasa en una ética comunitaria, cuya idea central radica en la estrecha conexión entre el entorno biofísico y los seres bumanos. No existe la escisión occidental entre las personas y los bienes [...]”. (Florez 2008, p. 111).

Ora, é o indispensável compartilhamento e cuidado que tornam um bem "comum”, cuja percepção é a principal motivação pela qual grupos humanos se organizam socialmente e "criam" bens comuns. Assim,

Ser comum é ser um direito coletivo. Não é uma questão de propriedade. Não é "de ninguém", mas de todos. Não é só ser público que garante ser de todos [...] O privado é o que é controlado privadamente, segundo interesses particulares. O que é público, controlado ou não pelo Estado, deve atender a interesses coletivos, de todas e todos. Mas para isto necessariamente precisa ser visto e tratado como um comum, um direito igual de todos e todas da coletividade. (Grzybowski 2014).

Faz-se necessário então uma profunda mudança de mentalidade para a saída de uma sociedade do "ter e acumular" em direção ao bem viver, que tem como pressuposto o compartilhamento dos bens comuns (Grzybowski 2012).

Em suma, a busca por alternativas à racionalidade antropocêntrica e ao modelo de produção e de consumo dominantes tornou-se um imperativo para a manutenção da própria vida no planeta e, a partir das práticas constituintes ocorridas recentemente na América Latina, visualiza-se a possibilidade e a necessidade de pensar e agir para além da lógica estatal e buscar novas teorias e novas práticas institucionais que apontam para as possibilidades concretas do comum, em direção a um sistema de vida voltado aos ecossistemas e à coletividade (Acosta 2010).

A Constituição brasileira de 1988, ainda que ofereça diversos mecanismos de proteção ambiental, não consegue transcender as limitações do antropocentrismo enraizado historicamente, à medida que atribui ao Estado e à Sociedade a obrigação de garantir e promover um meio ambiente ecologicamente equilibrado, consolidando a centralidade humana sobre a natureza, estabelecendo relação de subordinação e tutela.

Assim sendo, a partir da análise da Constituição equatoriana de 2008 é possível visualizar a necessidade de se pensar e agir para além da lógica estatal, em direção a um sistema de vida voltado aos ecossistemas e a um modelo de produção possível e viável, possibilitando a articulação e convergência entre o comum e conceitos que procedem de tradições distintas à ocidental e emergem partir de processos de lutas de insurgência popular. Em suma, a tarefa que se tem em vista é a de construir sistemas adequados de proteção aos bens comuns e de ampliação dos direitos da natureza, para além de uma concepção utilitarista. 


\section{Conclusão}

No Brasil o meio ambiente é tutelado formalmente pela Constituição Federal de 1988, tendo sido reservado um capítulo inteiro para garantir o equilíbrio ecológico, declarando ser o meio ambiente um bem de uso comum do povo, essencial para a sadia qualidade de vida. No entanto, tal salvaguarda é fruto de prescrições normativas internacionais, não de conquistas de movimentos sociais nacionais, tratando-se, portanto, de uma imposição, não de uma conquista, tampouco desejo popular. Sendo verificado que pela constituição brasileira restou consagrado um bem que não é público, tampouco privado, desvinculado dos institutos civis de posse e propriedade, não podem ser apropriado individualmente como a propriedade privada, criando-se a partir disso um "terceiro gênero de bem", de titularidade indefinida, de caráter coletivo, o então chamado direito difuso ao meio ambiente ecologicamente equilibrado.

E, ao tornar o meio ambiente bem de uso comum do povo, como dispõe o artigo 225 da constituição brasileira, seria o mesmo que determinar que tal bem, por sua própria natureza, pode ser utilizado por todos em igualdade de condições, sem necessidade de consentimento individualizado por parte da administração. Porém, no Brasil o meio ambiente tem status de bem jurídico, não por existir importância social, mas sim econômica. Contexto que revela que no ordenamento jurídico brasileiro há certa frieza com relação a proteção ao meio ambiente, há apenas normatizações que carecem de respeito ambiental, não refletindo a verdadeira importância da natureza para a humanidade.

Ao contrário ocorre no contexto equatoriano, que tem em seu texto constitucional o reflexo das próprias lutas de seu povo, emergindo o buen vivir fundado nas cosmovisões dos povos indígenas, assegurando direitos próprios à natureza e direitos ao desenvolvimento do bem viver, assim como sobre a introdução da natureza como sujeito de direitos. Não como um bem jurídico a ser tutelado, como no Brasil, mas em si mesmo como sujeito de direitos. Aqui a expressão buen vivir refere-se à busca do bem viver respeitando os direitos da própria "mãe natureza", patrimônio comum da vida.

A Constituição equatoriana faz referência à realização dos bens comuns, consagrando a água, a alimentação, o ambiente sadio, a cultura, a educação, o babitat, a moradia, a saúde, o trabalho e a segurança, como bens associados à vida e ao bem viver, em que faz ressurgir a cosmovisões andinas, emergindo o "novo" constitucionalismo latinoamericano e o bem comum. Isso contrapõe-se ao dogmatismo brasileiro que trata o meio ambiente como bem jurídico que pode vir a ser tutelado, não por respeito a quem nos concede a preservação da vida humana, mas especificamente para manter a vida econômica do ser humano no patamar em que se encontra.

Ousa-se dizer que por tais motivos será difícil vivenciar uma real preservação ambiental em território brasileiro, pois perdeu-se o sentimento dos povos originários de "mãe natureza", de vida em comunidade, do comum. Motivo pelo qual, diante deste estudo, concluiu-se ser necessário a construção de sistemas adequados de proteção do "comum" e dos direitos da natureza no Brasil. Pois, muito embora o "comum" em ambos ordenamentos sejam similares, no cenário equatoriano o "comum" refere-se aos espaços, os artefatos, os eventos e as técnicas culturais que são de uso e gozo comum e cuja posse coletiva implica direitos, responsabilidades, restrições e consciência da relação vital entre entes e seus recursos comuns, há uma enfoque de "descoisificar", uma vez que ao tratar a natureza como "coisa comum", se está afastando o sentido da relação social vinculada à ideia de diversidade de recursos, comunidades e de formas de gestão, aqui há ética comunitária, com extrema conexão entre a natureza e os seres humanos.

A partir do "comum" presente no "novo" constitucionalismo latino-americano há uma busca alternativas à racionalidade antropocêntrica e ao modelo de produção e de consumo dominantes, imperativo para a manutenção da própria vida no planeta. A constituição brasileira de 1988 consolida a centralidade humana sobre a natureza, estabelecendo relação de subordinação e tutela. Motivos pelos quais se prima pela construção de sistemas adequados de proteção do "comum" e de ampliação dos direitos da natureza, para além de uma concepção utilitarista. 


\section{REFERÊNCIAS}

Acosta A. El buen vivir en el camino del post-desarrollo: una lectura desde la Constitución de Montecristi. Berlim: FES, 2010. Policy Paper 9, 43 p.

Acosta A e Gudynas E. La renovación de la crítica al desarrollo y el buen vivir como alternativa. Journal of Sustainability Education, mar. 2012.

Bernardes MS. A (re)invenção do comum no novo constitucionalismo latino-americano: ecologia política, direito e resistência na américa latina. 2017. 311 f. Tese (Doutorado em Direito) - Centro de Ciências Jurídicas, Universidade Federal de Santa Catarina, Florianópolis, 2017, 308 p.

Bollier D. Pensar desde los comunes: una breve introducción. Primera edición colaborativa: Sursiendo, Traficantes de Sueños, Tinta Limón, Cornucopia e Guerrilla Translation. Noviembre, 2016. Hamherst: Commons Strategies Group, 2016, $196 \mathrm{p}$.

Brasil. Constituição da República Federativa do Brasil. Disponível em: <http://www.planalto.gov.br/ccivil_03/ constituicao/constitui\%C3\%A7ao.htm> Acesso em 18 jan 2018 a.

Brasil. Lei $\mathbf{n}^{\mathbf{0}}$ 6.938, de 31 de agosto de 1981: dispõe sobre a Política Nacional do Meio Ambiente, seus fins e mecanismos de formulação e aplicação, e dá outras providências. <http://www.planalto.gov.br/ccivil_03/leis/L6938.htm > Acesso em 18 jan 2018b.

Brasil. Lei $\mathbf{n}^{\circ}$ 7.347, de 24 de julho de 1985: disciplina a ação civil pública de responsabilidade por danos causados ao meio-ambiente, ao consumidor, a bens e direitos de valor artístico, estético, histórico, turístico e paisagístico e dá outras providências. <http://www.planalto.gov.br/ccivil_03/leis/17347orig.htm> Acesso em 18 jan 2018c

Brasil. Lei no 4.717, de 29 de junho de 1965: Regula a ação popular. <http://www.planalto.gov.br/Ccivil_03/leis/L4717. htm> Acesso em 18 jan 2018d

Brandão PAD. O novo constitucionalismo pluralista latino-americano: participação popular e cosmovisões indígenas (pachamama e sumak kawsay). 2013. Dissertação (Mestrado em Direito) - Faculdade de Direito do Recife/Centro de Ciências Jurídicas da Universidade Federal de Pernambuco, Recife, 2013, 154 p.

Canotilho JJG. Estudos sobre direitos fundamentais. 1. ed. São Paulo: Revista dos Tribunais; Portugal: Coimbra Editora, 2008. $273 \mathrm{p}$.

Di Pietro MSZ. Direito administrativo. 4 ed. São Paulo: Atlas, 1994. 567 p.

Equador. Constitución del Ecuador. 2008. Disponível em: <http://www.asambleanacional.gov.ec/documentos/ constitucion_de_bolsillo.pdf >. Acesso em: 09 mai 2018.

Ferrazzo D. Pluralismo Jurídico e Descolonização Constitucional na América Latina. 2015. Dissertação. Mestrado em Direito - Universidade Federal de Santa Catarina, Florianópolis, 2015, 462 p.

Flórez M. Lo público? Lo común? O lo nuestro, lo de todos! In: Helfrich S. Genes, bytes y emisiones: bienes comunes y ciudadanía. Fundación Heinrich Böll, Oficina Regional para Centroamérica, México y Cuba, Agosto de 2008, p 109-114, 96890-84-02-X 
Fiorillo CAP. Curso de direito ambiental brasileiro. 12. ed., rev. atual. ampl. São Paulo: Saraiva, 2011. 866 p.

Grzybowski C. Bens comuns e bem viver. Passerelle, n. 6, jun. 2012. Os bens comuns modelo de gestão dos recursos naturais. Disponível em: <https://www.coredem.info/IMG/pdf/bens_comuns.pdf >. Acesso em: 10 mar. 2018, p. 16-19.

Grzybowski C. Água: um bem comum. Carta Maior, 25 mar. 2014. Disponível em: <https://www.cartamaior.com.br/?/ Editoria/Meio-Ambiente/agua-um-bem-comum/3/30555>. Acesso em: 5 fev. 2018.

Helfrich S. Bienes comunes y ciudadanía: uma invitación a compartir. In: Helfrich S. Genes, bytes y emisiones: bienes comunes y ciudadanía. Fundación Heinrich Böll, Oficina Regional para Centroamérica, México y Cuba, Agosto de 2008ª p 21-26, 96890-84-02-X.

Grzybowski C. Commons: âmbitos o bienes comunes, procomún o "lo nuestro". In: Helfrich S. Genes, bytes y emisiones: Bienes comunes y ciudadanía. Fundación Heinrich Böll, Oficina Regional para Centroamérica, México y Cuba, Agosto de 2008b, p 42-48, 96890-84-02-X.

Medici AM. Teoría constitucional y giro decolonial: narrativas y simbolismos de las constituciones, Reflexiones a propósito de la experiencia de Bolivia y Ecuador. Revista de Estudios Críticos, Universidad Nacional del Comahue, n.1, p. 94-124, 2011.

Moraes A. Direito constitucional. 26. ed. São Paulo: Atlas, 2011.

Oliveira OMBA. Monografia Jurídica: orientações metodológicas para o Trabalho de Conclusão de Curso. Porto Alegre: Síntese, 1999.

Preve DR; Filó MCS; May YO. Ensaio sobre o Estado de direito ambiental: conceito, mecanismo e desafio. Curitiba: Multidéia, 2016. 80 p.

Rivera Lugo C. La constitución de lo común. Rev. Direito e Práxis, Rio de Janeiro, v. 8, n. 4, 2017, p. 3217-3231, 10.1590/2179$8966 / 2017 / 31316$.

Souza ASR. O meio ambiente como direito difuso e a sua proteção como exercício e cidadania. 2010. Disponível em: <http://periodicos.pucminas.br/index.php/Direito/article/view/P.2318-7999.2010v13n25p22/3956> acessado em: 30 de abril de 2018.

Tera ambiental. As principais leis ambientais brasileiras. 2015. Disponível em: $<$ http:/ /www.teraambiental.com.br/blogda-tera-ambiental/as-principais-leis-ambientais-brasileiras> acessado em: 30 de abril de 2018.

Verdum R. Povos Indígenas no Brasil: o desafio da autonomia. Verdum R (Org.). Povos indígenas: constituições e reformas políticas na América Latina. Brasília: IES, 2009, p. 91-112.

Wolkmer AC. Pluralismo crítico e perspectivas para um novo constitucionalismo na América Latina. In: Wolkmer AC; Melo MP. (Org.). Constitucionalismo latino-americano: tendências contemporâneas. Curitiba: Juruá, 2013. p. 19-42. v. 1.

Wolkmer AC e Wolkmer MFS. Novos horizontes na produção do conhecimento: pluralismo, direitos humanos e a questão dos bens comuns. In:

Neto, JS (Org.). Novos direitos na América Latina: estudo comparativo como instrumento de reflexão do próprio direito. São Luís: Edufma, 2016. 
Wolkmer AC e Wolkmer MFS. Perspectiva do buen vivir na América Latina: o diálogo intercultural para um horizonte póscapitalista. In: Silveira BGM; Araújo LA; Andrade PC (Org.). Direito das minorias no novo ciclo de resistências na América Latina. Coordenação de Raquel Coelho de Freitas e Germana de Oliveira Moraes. Curitiba: CRV, 2017. 